\title{
Energy and protein requirements during the growing phase of indigenous goats
}

\section{Exigências de proteína e energia durante a fase de crescimento de caprinos sem padrão racial definido}

\author{
Kléber Tomás Resende ${ }^{1}$; Silvio Doria de Almeida Ribeiro²; \\ Amélia Katiane de Almeida ${ }^{3}$; Marcelo Teixeira Rodrigues ${ }^{4}$; José Américo Garcia ${ }^{5}$; \\ Izabelle Auxiliadora Molina de Almeida Teixeira ${ }^{1}$
}

\begin{abstract}
The objective of this study was to investigate both energy and protein requirements for the maintenance and growth of indigenous goats, based on data from two separate studies. Goats were weaned at 79 \pm 4.4 days of age, with milk and solid diet intake recorded daily. To determine energy maintenance requirements, 32 kids of $4.90 \pm 0.302 \mathrm{~kg}$ initial body weight (BW) were used. Ten kids were slaughtered at $5.40 \pm 0.484 \mathrm{~kg} \mathrm{BW}$ to estimate initial body composition, with the remaining kids randomly assigned to one of two DM intake levels: ad libitum and restricted-fed (1.2-times maintenance level). Heat production (HP) was calculated as the difference between ingested metabolizable energy (MEI) and retained energy. Net energy requirement for maintenance $\left(\mathrm{NE}_{\mathrm{m}}\right)$ was estimated as the $\beta_{0}$ parameter of the relationship between HP and MEI $\left[\mathrm{HP}=\beta_{0} \times \exp ^{(\beta 1 \times \mathrm{MEI})}\right]$. Metabolizable energy required for maintenance $\left(\mathrm{ME}_{\mathrm{m}}\right)$ was calculated iteratively, as $\mathrm{HP}=\mathrm{MEI}$. Efficiency of energy utilization for maintenance $\left(\mathrm{k}_{\mathrm{m}}\right)$ was calculated as $\mathrm{NE}_{\mathrm{m}} / \mathrm{ME}_{\mathrm{m}}$. The intercept of the linear regression of retained $\mathrm{CP}$ on CP intake was used to calculate net protein requirements for maintenance $\left(\mathrm{NP}_{\mathrm{m}}\right)$. Net energy and protein requirement for gain ( $\mathrm{NE}_{\mathrm{g}}$ and $\mathrm{NP}_{\mathrm{g}}$, respectively) were obtained using 26 kids fed ad libitum and randomly slaughtered at $5.40 \pm 0.484 \mathrm{~kg} \mathrm{BW}(\mathrm{n}=10), 15.8 \pm 0.655 \mathrm{~kg} \mathrm{BW}(\mathrm{n}=10)$, and $26.3 \pm 1.27 \mathrm{~kg}$ BW $(n=6)$. The first derivative of the allometric equation (used to calculate energy and protein contents in empty body weight (EBW)) with respect to EBW yielded estimates of $\mathrm{NE}_{\mathrm{g}}$ and $\mathrm{NP}_{\mathrm{g}}$. A Monte Carlobased method was employed to simulate variation in $\mathrm{ME}_{\mathrm{m}}, \mathrm{NE}_{\mathrm{g}}$, and $\mathrm{NP}_{\mathrm{g}}$. This study indicated that the net energy required for maintenance is $310.1 \pm 36.7 \mathrm{~kJ} \mathrm{~kg}^{-0.75} \mathrm{EBW}$, with $\mathrm{ME}_{\mathrm{m}}$ estimated at $499.1 \pm 52.1$

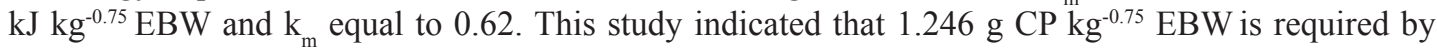
indigenous kids weighing from 5 to $25 \mathrm{~kg} \mathrm{BW}$ to meet their $\mathrm{NP}_{\mathrm{m}}$. In addition, indigenous goats require between $186.6 \pm 2.97$ and $214.3 \pm 12.9 \mathrm{~g} \mathrm{CP}$, and between $5.39 \pm 1.49$ and $9.74 \pm 2.57 \mathrm{MJ}$ to gain one kilogram of EBW. This study may contribute to future adjustments in feeding system energy and protein recommendations for indigenous kids.
\end{abstract}

Key words: Body composition. Comparative slaughter. Gain. Maintenance

\section{Resumo}

Objetivou-se com o presente estudo, investigar as exigências de proteína e energia para mantença e ganho de caprinos sem padrão racial definido. Para tal, foram utilizados dados individuais de caprinos

${ }^{1}$ Profs., Universidade Estadual Paulista, UNESP, Jaboticabal, SP, Brasil. E-mail: kresende@fcav.unesp.br; izabelle@fcav.unesp.br

2 Consultor, Capritec, Juazeiro, BA, Brasil. E-mail: silvio@capritec.com.br

3 Pesquisador, UNESP, Jaboticabal, SP, Brasil. E-mail: ameliaalmeida@fcav.unesp.br

${ }^{4}$ Prof., Universidade Federal de Viçosa, UFV, Viçosa, MG, Brasil. E-mail: mtrodrig@ufv.br

5 Prof., UFV, Viçosa, MG, Brasil. In memorian.

* Author for correspondence 
de 2 estudos. Os caprinos foram desmamados com $79 \pm 4,4$ dias de idade. Ingestão de leite e dieta sólida foi tomada diariamente. Utilizou-se 32 cabritos de 4,90 $\pm 0,302 \mathrm{~kg}$ de peso corporal (PC) inicial. Nesse momento, 10 cabritos foram abatidos para estimativa de composição corporal inicial. Os cabritos remanescentes foram distribuídos aleatoriamente em dois níveis de ingestão: ad libitum ou com ingestão de $20 \%$ acima do nível de mantença. A produção de calor (C) foi calculada pela diferença da energia metabolizável (IEM) ingerida e energia retida. A energia líquida para manteça $\left(\mathrm{EL}_{\mathrm{m}}\right)$ foi estimada pelo parâmetro $\beta_{0}$ da relação entre C e IEM $\left[\mathrm{C}=\beta_{0} \times \exp ^{(\beta 1 \times \text { IEM) }}\right]$ A exigência de energia metabolizável para mantença $\left(E M_{m}\right)$ foi calculada quando $C=$ IEM. A eficiência de utilização de energia para mantença $\left(k_{m}\right)$ foi calculada por $\mathrm{EL}_{\mathrm{m}} / \mathrm{EM}_{\mathrm{m}}$. Utilizou-se o intercepto da regressão linear da proteína retida pela proteína bruta $(\mathrm{PB})$ ingerida para estimativa da proteína líquida exigida para mantença $\left(\mathrm{PL}_{\mathrm{m}}\right)$. A exigência líquida de proteína e energia para ganho $\left(\mathrm{EL}_{\mathrm{g}}\right.$ e $\mathrm{PL}_{\mathrm{g}}$, respectivamente) foram obtidas utilizando-se 26 cabritos alimentados à vontade e abatidos aos 5,40 $\pm 0,484 \mathrm{~kg} \mathrm{PC}(\mathrm{n}=10), 15,8 \pm 0,655 \mathrm{~kg} \mathrm{PC}(\mathrm{n}=10)$ e 26,3 $\pm 1,27 \mathrm{~kg}$ PC $(\mathrm{n}=6)$. A EL $\mathrm{g}_{\mathrm{g}}$ e $\mathrm{PL}_{\mathrm{g}}$ foram estimadas pela derivada parcial da equação alométrica (i.e., gerada para estimar o conteứdo de energia e proteína no corpo vazio). A simulação de Monte Carlo foi empregada para simular a variação das estimativas da $\mathrm{EM}_{\mathrm{m}}, \mathrm{EL}_{\mathrm{g}} \mathrm{e} \mathrm{PL}_{\mathrm{g}}$. Os resultados do presente estudo indicam que a energia líquida necessária para mantença é $310,1^{\mathrm{m}} \pm 36,7 \mathrm{~kJ} \mathrm{~kg}^{-0,75} \mathrm{PC}$ vazio, e que a $\mathrm{EM}_{\mathrm{m}}$ é igual a $499,1 \pm 52,1 \mathrm{~kJ} \mathrm{~kg}^{-0,75} \mathrm{PC}$ vazio, com $\mathrm{k}_{\mathrm{m}}$ de 0,62 . Este estudo indicou que $1,246 \mathrm{~g} \mathrm{~PB} \mathrm{~kg}^{-0,75} \mathrm{PCV}$ é exigido por cabritos sem padrão racial definido entre 5 a $25 \mathrm{~kg}$ PC para atender a $\mathrm{PL}_{\mathrm{m}}$. Adicionalmente, cabritos sem padrão racial definido entre 5 a $25 \mathrm{~kg}$ PC requerem entre 186,6 $\pm 2,97 \mathrm{a} 214,3 \pm 12,9 \mathrm{~g}$ de proteína, e 5,39 $\pm 1,49$ a 9,74 $\pm 2,57$ MJ de energia para ganhar um quilo de PC vazio. O presente estudo pode contribuir para futuros ajustes nas atuais recomendações de energia e proteína para cabritos sem padrão racial definido pelos sistemas de alimentação.

Palavras-chave: Composição corporal. Abate comparativo. Ganho. Mantença.

\section{Introduction}

The world goat population increased by $18.3 \%$ (from 849 million to over one billion heads) between 2004 and 2014 (FAO, 2014). In least developed countries (according to FAO classification), the goat stock in heads increased by $35 \%$ during the same period, from 237 million heads in 2004 to 319 million heads in 2014; (FAO, 2014), indicating that goat production may play an important role in alleviating poverty.

For instance, indigenous goats demonstrate strong adaptability depending on the local conditions in which they were raised and selected. In this sense, energy and nutrient requirements may be affected by genetic selection and crossbreeding (FERNANDES et al., 2007). Thus, the production efficiency of indigenous goats is expected to be lower than that observed in highly productive breeds. Variation in adaptability, driven by genotype, is one of the major reasons behind the lack of precise knowledge regarding these animals' energy and nutrient requirements, which may limit the profitability and efficiency of the feeding program in a herd.
Moreover, the guidelines most commonly used to formulate diets for goat production are currently based on recommendations from the NRC (2007), which guide for corrections in energy requirements but not in protein. Furthermore, feeding systems such as those of the CSIRO (2007) and AFRC (1993) do not take into account any differences among genotypes. Because net requirements for gain are dictated by the tissue deposited in the body at any given point on the growth curve, we hypothesize that net requirements will follow the pattern of energy and protein deposition in indigenous goat kids.

Therefore, the objective of this study was to estimate energy and protein requirements for the maintenance and gain of indigenous goats. This information should support producers in formulating diets for growing indigenous goats, improving feeding program suitability in a herd.

\section{Materials and Methods}

Individual records of 38 indigenous male kids from two studies conducted at the Universidade 
Federal de Viçosa, Minas Gerais, (205'S; $42^{\circ} 52^{\prime} \mathrm{W}, 649 \mathrm{~m}$ altitude) in collaboration with UNESP - Univ Estadual Paulista, Jaboticabal, São Paulo, (2114'S; 48¹7’W, $595 \mathrm{~m}$ altitude), were used. The field phase was carried out at the Universidade Federal de Viçosa. This database combined data from two studies in which the body weight (BW) of kids ranged from 5 to $25 \mathrm{~kg}$ (study 1), and from 5 to $15 \mathrm{~kg}$ (study 2).

\section{General procedures}

From birth to their $10^{\text {th }}$ day of life, kids were allocated to individual $1 \mathrm{~m}^{2}$ pens. Afterwards, towards the end of the experiment, they were allocated to individual $1.5 \mathrm{~m}^{2}$ pens. Male kids were weaned at $79 \pm 4.4$ days of age. Milk was supplied at $07 \mathrm{~h} 00$ and $17 \mathrm{~h} 00$ in such a way that ad libitum kids received $123.8 \pm 6.42 \mathrm{~g} \mathrm{DM}$, and restricted kids $34.7 \pm 3.09$ g DM, daily. Kids in both studies were fed similar solid diets (Table 1), with food provided daily at $08 \mathrm{~h} 00$ and $16 \mathrm{~h} 00$.

Table 1. Ingredient and chemical composition of the diet.

\begin{tabular}{lccccc}
\hline \multirow{2}{*}{ Ingredient } & $\begin{array}{c}\text { Composition } \\
(\%, \text { DM basis })\end{array}$ & GE & CP & NDF & ADF \\
\cline { 2 - 5 } & 58.7 & 17.1 & 10.5 & 73.9 & 43.5 \\
Oat hay & 29.3 & 18.0 & 9.58 & 28.5 & 4.00 \\
Ground corn & 10.3 & 19.1 & 52.5 & 22.3 & 11.7 \\
Soybean meal & 0.750 & - & - & - & - \\
Limestone & 0.600 & - & - & - & - \\
Mineral supplement & 0.350 & - & - & - & - \\
Dicalcium phosphate & 100 & 17.3 & 14.4 & 54.0 & 27.9 \\
Total diet & &
\end{tabular}

${ }^{*} \mathrm{DM}=$ dry matter; $\mathrm{CP}=$ crude protein; $\mathrm{NDF}=$ neutral detergent fiber; $\mathrm{ADF}=$ acid detergent fiber; $\mathrm{GE}=$ gross energy $(\mathrm{MJ} / \mathrm{kg} \mathrm{DM})$. $\$ 98.4 \% \mathrm{NaCl} ; 0.593 \% \mathrm{FeSO}_{4} ; 0.593 \% \mathrm{ZnSO}_{4} ; 0.273 \% \mathrm{CuSO}_{4} ; 0.07 \% \mathrm{CoSO}_{4} ; 0.018 \% \mathrm{KI} \mathrm{O}_{3}$.

\section{Slaughter procedures and chemical analyses}

Both studies adopted similar slaughter procedures and chemical analyses. BW was measured immediately before feed and water were withdrawn for $16 \mathrm{~h}$. Shrunk BW was measured immediately before slaughter, after $16 \mathrm{~h}$ fasting. At slaughter, kids were stunned and slaughtered by exsanguination. The digestive tract was weighed before and after it was emptied. Empty BW (EBW) was computed as shrunk BW minus the weight of the contents of the digestive tract, bladder, and biliary vesicle. The empty whole body was then ground, homogenized, and sampled for further chemical determination. Sub-samples were dried for $72 \mathrm{~h}$ at 55 to $60^{\circ} \mathrm{C}$, and ground using a ball mill. All sub-samples were then analyzed for moisture, ash, fat and protein according to AOAC (1980), and energy (using a "Parr" calorimetric bomb).

\section{Trial 1 - Maintenance requirements}

A total of 32 kids (18 from study 1 and 14 from study 2) were used. From this group, 10 goats were randomly selected for slaughter at the beginning of the trial (6 from study 1 and 4 from study 2). These animals, hereafter referred to as the baseline (BL) group, were used to estimate the initial body composition of the animals in the maintenance trial, as described by Lofgreen and Garret (1968). The remaining goats (12 goats from study 1 and 10 from study 2) were randomly allocated to one of two treatments based on intake level: ad libitum or restricted-fed, who consumed $20 \%$ more feed on top of maintenance requirements (i.e., $1.2 \times$ maintenance level, namely $1.2 \times \mathrm{L}$ ), forming blocks of 2 goats. Thus, the intake goat fed at maintenance level within a block was calculated based on the dry matter intake (DMI) of the ad libitum goat during 
the previous day. Kids were slaughtered when the animal fed ad libitum reached the targeted final BW $(26.3 \pm 0.550 \mathrm{~kg}$ at $178 \pm 32$ days in study 1 , and $15.6 \pm 0.356 \mathrm{~kg}$ at $71 \pm 49$ days in study 2). Ad libitum rationing was adjusted daily based on the DMI for the previous day plus $20 \%$.

Heat production (HP, $\mathrm{kJ} \mathrm{kg}^{-0.75}$ EBW daily) was calculated as the difference between ME intake (MEI, $\mathrm{kJ} \mathrm{kg}^{-0.75} \mathrm{EBW}$ daily) and retained energy (RE, $\mathrm{kJ} \mathrm{kg}^{-0.75} \mathrm{EBW}$ daily). A non-linear model was used to describe the relationship between HP and MEI, and was performed according to Eq. [1]. Net energy requirement for maintenance $\left(\mathrm{NE}_{\mathrm{m}}\right)$ was estimated as the $\beta_{0}$ parameter in Eq. [1]. The ME required for maintenance $\left(\mathrm{ME}_{\mathrm{m}}, \mathrm{kJ} \mathrm{kg}^{-0.75} \mathrm{EBW}\right)$ was calculated iteratively, with the maintenance requirement equal to the value at which HP is equal to MEI.

$$
\mathrm{HP}=\beta_{0} \times \exp ^{\beta 1 \times \mathrm{MEI}}+\varepsilon
$$

where $H P$ is daily heat production $\left(\mathrm{kJ} \mathrm{kg}^{-0.75} \mathrm{EBW}\right)$, $\beta_{0}$ and $\beta_{l}$ are the parameter estimates, $M E I$ is daily ME intake $\left(\mathrm{kJ} \mathrm{kg}^{-0.75} \mathrm{EBW}\right)$, and $\varepsilon$ is the residual.

The efficiency of energy utilization for maintenance $\left(\mathrm{k}_{\mathrm{m}}\right)$ was calculated as $\mathrm{NE}_{\mathrm{m}} / \mathrm{ME}_{\mathrm{m}}$. The partial efficiency of ME utilization for growth $\left(\mathrm{k}_{\mathrm{g}}\right)$ was assumed to be the slope of the linear regression of RE on MEI above the maintenance level (MEI $)$, assuming that RE is null when $\mathrm{MEI}_{\mathrm{g}}=0$ (model intercept equal to 0), according to Galvani et al. (2014).

Linear regression of retained crude protein $(\mathrm{CP} ; \mathrm{g}$ $\mathrm{CP} \mathrm{kg}^{-0.75} \mathrm{EBW}$ daily) on CP intake (CPI; $\mathrm{g} \mathrm{CP} \mathrm{kg}{ }^{-0.75}$ EBW daily) was carried out to calculate net protein requirements for maintenance $\left(\mathrm{NP}_{\mathrm{m}}\right)$. The intercept of regression (where retained $\mathrm{CP}=0$ ) was assumed to represent endogenous and metabolic losses of protein, which are in turn assumed to represent the net protein requirement for maintenance.

\section{Determination of diet digestibility}

A metabolism assay was carried out at the midpoint of the maintenance trial of study 1 . The BW of ad libitum-fed goat kids dictated the beginning of the assay. In this sense, all animals were sampled when goats fed ad libitum weighed, on average, $18.2 \pm 0.684 \mathrm{~kg}$ BW. Total feces and urine collection was carried out to determine DE, ME and the metabolizability of energy (q) of the diet on each level of intake.

During the metabolism assay, animals were housed in individual metabolic cages. Feeds, orts, feces, and urine were collected during $5 \mathrm{~d}$ after a 3-d adaptation period to the cage. Urine was acidified daily with $20 \mathrm{~mL}$ of $20 \%$ sulfuric acid. Feeds and orts were sampled daily and immediately stored at $-20{ }^{\circ} \mathrm{C}$. Feces and urine were weighed daily. A representative sample of feces and urine, approximately $10 \%$ of the daily mass, were taken and stored at $-20^{\circ} \mathrm{C}$.

Nutrients and energy was determined for feeds, orts, feces and, urine. Digestible nutrients and energy was computed from their content in feeds, orts and feces. The metabolizable energy was determinate from GE of feeds, orts, feces, urine, and the energy from gaseous products was estimated as reported by Blaxter and Clapperton (1965).

\section{Trial 2 - Growth requirements}

Net energy and protein requirements for gain were estimated using 26 indigenous intact males (12 kids from study 1 and 14 from study 2). The animals were fed ad libitum and slaughtered at targeted BW values of 5 or $25 \mathrm{~kg}$ (study 1), and 5 or $15 \mathrm{~kg}$ (study 2). From the body composition of these goats, allometric equations (Eq. [2]) were fitted to estimate body composition (protein, fat, energy, and ash contents) from EBW (kg) according to ARC (1980). 


$$
\mathrm{Y}=\beta_{0} \times \mathrm{EBW}^{\beta 1}+\varepsilon
$$

where $Y$ is the amount of protein, fat, and ash $(\mathrm{g})$, or energy (MJ) in EBW, $\beta_{0}$ and $\beta_{l}$ are the parameter estimates, $E B W$ in $\mathrm{kg}$, and $\varepsilon$ is the residual.

The first derivative of Eq. [2] with respect to EBW yields an estimate of $\mathrm{NE}_{\mathrm{g}}$ and $\mathrm{NP}_{\mathrm{g}}$ at various EBW values (Eq. [3]):

$$
\mathrm{Y}^{\prime}=\beta_{1} \times \beta_{0} \times \mathrm{EWG}^{(\beta 1-1)}+\varepsilon
$$

where $Y^{\prime}$ is energy $\left(\mathrm{KJ} \mathrm{kg}^{-1}\right)$ or protein $\left(\mathrm{g} \mathrm{kg}^{-1}\right)$ concentration per unit of EBW (EWG, $\mathrm{kg}) ; \beta_{0}$ and $\beta_{l}$ are the parameter estimates of the allometric equation (Eq. [2]) and $\varepsilon$ is the residual.

\section{Statistical analyses}

Data from the maintenance trial were analyzed in a completely randomized block design using a mixed model with the fixed effect intake level and the random effect of study, according to the model:

$$
\mathrm{Y}_{\mathrm{ij}}=\mu+\mathrm{L}_{\mathrm{i}}+\mathrm{S}_{\mathrm{j}}+\mathrm{e}_{\mathrm{ij}}
$$

where, $\mathrm{Y}_{\mathrm{ij}}=$ expected outcome for the dependent variable $\mathrm{Y} ; \mu=$ overall mean; $\mathrm{L}_{\mathrm{i}}=$ fixed effect of the $i^{\text {th }}$ level of intake; $S_{j}=$ random effect of the $j^{\text {th }}$ study; and $\mathrm{e}_{\mathrm{ij}}$ is the random residual error, assumed to be $\simeq \mathrm{N}\left(0, \sigma_{\mathrm{e}}{ }^{2}\right)$.

The allometric equation was generated using the baseline animals to estimate initial body composition (energy and protein). These were fitted using the PROC NLIN and MARQUARDT methods available in SAS (SAS - Statistical Analysis System; Institute Inc., Cary, NC version 9.4). To fit the nonlinear model of HP on MEI, the PROC NLMIXED procedure (SAS Inst. Inc., Cary, $\mathrm{NC}$; version 9.4) was employed. Linear regression analyses (i.e., retained $\mathrm{N}$ on $\mathrm{N}$ intake, and $\mathrm{EBW}$ on $\mathrm{BW})$ were performed using the MIXED procedure.
Data from gain trial was analyzed as a completely randomized design with fixed effect slaughter BW, according to the model:

$$
\mathrm{Y}_{\mathrm{ij}}=\mu+\mathrm{W}_{\mathrm{i}}+\mathrm{e}_{\mathrm{ij}}
$$

where $\mathrm{Y}_{\mathrm{ij}}=$ expected outcome for the dependent variable $\mathrm{Y} ; \mu=$ overall mean; $\mathrm{W}_{\mathrm{i}}=$ fixed effect of the $i^{\text {th }}$ slaughter weight; and $\mathrm{e}_{\mathrm{ij}}$ is the random residual error, assumed to be $\simeq \mathrm{N}\left(0, \sigma_{\mathrm{e}}^{2}\right)$.

Allometric equations were fitted using the PROC NLMIXED procedure (SAS Inst. Inc., Cary, $\mathrm{NC}$; version 9.4). After parameter estimation, the the allometric equation ((Eq. [2]) was associated with Monte Carlo statistical method (Markov chain), to simulate the first derivative of allometric equation variation, and then net energy and protein requirements for gain variation. For that, it was considered mean and standard deviation of parameters estimates, and their correlation to generate the dataset. Bivariate Normal techniques were analyzed using Bivariate 4.6, SAS for Monte Carlo Studies (FAN et al., 2002). The effect of the level of intake slaughter weight (i.e., body composition data) was decomposed into two orthogonal polynomial contrasts (linear and quadratic) and significance was declared at $\mathrm{P} \leq 0.05$.

\section{Results and Discussion}

During the metabolism trial, DMI, CPI, and MEI were greater $(\mathrm{P}<0.01)$ in kids under the ad libitum regimen than in those fed $1.2 \times \mathrm{L}$ (Table 2). However, these differences did not lead to differences in the digestibility coefficients of DM, $\mathrm{CP}$, and GE, or metabolizability $(\mathrm{P} \geq 0.12)$. The DMI of goats fed ad libitum was on average $63.0 \%$ greater $(\mathrm{P}<0.01)$ than for those fed $1.2 \times \mathrm{L}$ (Table $3)$, throughout the entire experimental period. For instance, observed DMI (3\% BW) was lower than the $4 \%$ BW predicted by the AFRC (1998), but similar to that reported previously for Saanen kids (FIGUEIREDO et al., 2017). 
Table 2. Intake, digestibility coefficients and metabolizability of male indigenous kids during metabolism trial.

\begin{tabular}{|c|c|c|c|c|}
\hline \multirow{2}{*}{ Item $^{1}$} & \multicolumn{2}{|c|}{ Level of intake } & \multirow{2}{*}{$\mathrm{SEM}^{3}$} & \multirow{2}{*}{$P$-value ${ }^{4}$} \\
\hline & $\mathrm{AL}$ & $1.2 \times \mathrm{L}$ & & \\
\hline$n$ & 6 & 6 & - & - \\
\hline $\mathrm{BW}, \mathrm{kg}$ & 18.2 & 10.0 & 0.238 & $<0.01$ \\
\hline DMI, g/d & 547.1 & 229.7 & 26.5 & $<0.01$ \\
\hline CPI, g/d & 95.3 & 33.2 & 3.74 & $<0.01$ \\
\hline GEI, MJ/d & 9.45 & 3.96 & 0.459 & $<0.01$ \\
\hline MEI, MJ/d & 5.54 & 2.35 & 0.261 & $<0.01$ \\
\hline DDM, \% & 71.4 & 71.6 & 1.40 & 0.93 \\
\hline DCP, \% & 71.5 & 67.5 & 1.66 & 0.12 \\
\hline DGE, \% & 69.4 & 70.2 & 1.55 & 0.74 \\
\hline$q$ & 0.589 & 0.591 & 0.0145 & 0.76 \\
\hline
\end{tabular}

${ }^{1} n=$ number of animals subjected to the metabolism trial; $\mathrm{BW}=$ body weight; $\mathrm{DMI}=$ dry matter intake; $\mathrm{CPI}=$ crude protein intake; $\mathrm{GEI}$ = gross energy intake; MEI = metabolizable energy intake; DDM = digestibility of dry matter; DCP = digestibility of crude protein; DGE $=$ digestibility of gross energy and $\mathrm{q}=$ metabolizability $(\mathrm{ME} / \mathrm{GE})$.

${ }^{2} \mathrm{Ad}$ libitum (AL) or $1.2 \times$ maintenance level (L).

${ }^{3}$ Standard error of the mean.

${ }^{4} P$-value of the intake level effect.

As retained $\mathrm{CP}$ was regressed against $\mathrm{CPI}$, the negative intercept (at $\mathrm{CPI}=0$ ) provided an estimate of minimum CP losses, as the sum of endogenous urinary CP and metabolic fecal CP (AFRC, 1998). This procedure indicated a value of $1.246 \mathrm{~g} \mathrm{CP} \mathrm{kg}^{-}$ ${ }^{0.75}$ EBW of $\mathrm{NP}_{\mathrm{m}}$ (Eq. [4]; $P<0.01 ; \sigma_{\mathrm{e}}^{2}=0.922$ ). The daily $\mathrm{CP}$ intake required for maintenance (retained $\mathrm{CP}=0$ ) was calculated at $4.45 \pm 1.24 \mathrm{~g}$ $\mathrm{CP} \mathrm{kg}{ }^{-0.75} \mathrm{EBW}$.
$C P_{\text {retained }}=-1.25 \pm 0.517+0.280 \pm 0.0347 \times C P_{\text {intake }}$

[4]

where $C P_{\text {retained }}$ is daily protein retention in the body ( $\left.\mathrm{g} \mathrm{CP} \mathrm{kg}^{-0.75} \mathrm{EBW}\right)$, and $C P_{\text {intake }}$ is daily $\mathrm{CP}$ intake ( $\mathrm{g}$ $\left.\mathrm{CP} \mathrm{kg}{ }^{-0.75} \mathrm{EBW}\right)$.

Table 3. Performance and body composition in male indigenous kids fed different levels of intake slaughtered at 15 or $25 \mathrm{~kg}$ of body weight.

\begin{tabular}{|c|c|c|c|c|c|c|}
\hline \multirow[t]{3}{*}{ Item $^{1}$} & \multicolumn{4}{|c|}{ Study (Level of intake) ${ }^{2}$} & \multirow{3}{*}{$\mathrm{SEM}^{3}$} & \multirow{3}{*}{$\begin{array}{l}P \text {-value } \\
\mathrm{I}\end{array}$} \\
\hline & \multicolumn{2}{|c|}{ Study 1} & \multicolumn{2}{|c|}{ Study 2} & & \\
\hline & $\mathrm{AL}$ & $1.2 \times \mathrm{L}$ & $\mathrm{AL}$ & $1.2 \times \mathrm{L}$ & & \\
\hline$n$ & 4 & 6 & 6 & 6 & - & - \\
\hline Days & 93.8 & 100.8 & 163 & 181 & - & - \\
\hline DMI, g/d & 440.7 & 167.2 & 581.9 & 209.9 & 24.3 & $<0.01$ \\
\hline Initial BW, kg & 4.99 & 4.80 & 4.91 & 5.04 & 0.246 & 0.34 \\
\hline Final BW, kg & 15.6 & 7.10 & 26.3 & 10.3 & 0.550 & $<0.01$ \\
\hline EBW, kg & 12.4 & 5.73 & 20.5 & 7.55 & 0.711 & $<0.01$ \\
\hline Water, g/kg EBW & 651.6 & 737.2 & 661.6 & 744.2 & 15.7 & $<0.01$ \\
\hline Protein, g/kg EBW & 178.7 & 178.9 & 206.5 & 184.4 & 9.19 & 0.24 \\
\hline Fat, g/kg EBW & 130.3 & 40.8 & 90.8 & 29.5 & 12.5 & $<0.01$ \\
\hline Energy, MJ/kg EBW & 9.64 & 6.26 & 8.53 & 6.06 & 0.368 & $<0.01$ \\
\hline Ash, g/kg EBW & 39.3 & 43.0 & 41.4 & 41.9 & 0.873 & 0.08 \\
\hline
\end{tabular}

${ }^{1} n$ = number of animals; BW = body weight; DMI = dry matter intake; EBW = empty body weight;

${ }^{2}$ Study (targeted slaughter weight of $15 \mathrm{~kg}$ - study 1 or $25 \mathrm{~kg}$ study 2 of body weight; was not considered as random effect because the purpose of this table is also to provide a description of each study; slaughter weights were dictated by ad libitum - AL goats. Those goats fed $1.2 \times \mathrm{L}$ - maintenance level were slaughtered with the same number of days of their pair-fed ad libitum goat.

${ }^{3}$ Standard error of the mean. ${ }^{4} P$-value for level of intake (I). 
The estimated $\mathrm{NP}_{\mathrm{m}}$ was $54.1 \%$ lower than that reported by the AFRC (1998); i.e., $2.2 \mathrm{~g} \mathrm{CP} \mathrm{kg}^{-0.75}$ $\mathrm{BW}$, and $67.1 \%$ lower than that recommended by the NRC (2007); i.e., $3.07 \mathrm{~g} \mathrm{CP} \mathrm{kg}^{-0.75} \mathrm{BW}$, respectively, considering an efficiency of use of metabolizable protein for maintenance equal to 1 . On the other hand, the digestible $\mathrm{CP}$ maintenance requirement estimated by Salah et al. (2014) for goats under warm climates is similar to that found in the present study (2.38 $\mathrm{g} \mathrm{kg}^{-0.75} \mathrm{BW}$ vs. $2.57 \mathrm{~g} \mathrm{~kg}^{-0.75} \mathrm{BW}$ ). When ruminants are subjected to hot environments, several physiological mechanisms may be affected in the digestive system, including acid-base status and blood hormone levels (WEST, 2003; YAZDI et al., 2016), as the animal attempts to maintain a stable body temperature. This effect may help to explain the disparity between recommended feeding systems that are based largely on information obtained from animals kept under temperate climates (AFRC, 1998; NRC, 2007), and results generated using animals studied under tropical conditions. Besides, it is likely that the efficiency of use of metabolizable protein for maintenance is less than 1, as previously stated by the AFRC (1998), and may also vary with diet. In addition, the $\mathrm{CP}$ required for maintenance estimated in the present study was $69.3 \%, 47.6 \%$ and $28.8 \%$ lower than that reported by Almeida et al. (2015b), Fernandes et al. (2007), and Ferreira et al. (2015), respectively, for dairy and crossbred goats. This discrepancy indicates that indigenous goats may lose less protein (i.e., via endogenous urinary $\mathrm{N}$, metabolic fecal $\mathrm{N}$, and dermal $\mathrm{N}$ losses) than goats of specialized breeds; in other words, differences across genotype may affect the animals' ability to recycle $\mathrm{N}$.

$\mathrm{NE}_{\mathrm{m}}$ was estimated at $310.1 \pm 36.7 \mathrm{~kJ} \mathrm{~kg}^{-0.75}$ EBW (Eq. [5]; $P<0.01 ; \sigma_{\mathrm{e}}^{2}=4028$ ), or $251.2 \mathrm{~kJ}$ $\mathrm{kg}^{-0.75} \mathrm{BW}$. Estimated $\mathrm{ME}_{\mathrm{m}}$ was thus equal to 499.1 $\pm 52.1 \mathrm{~kJ} \mathrm{~kg}^{-0.75} \mathrm{EBW}$ or $404.3 \mathrm{~kJ} \mathrm{~kg}^{-0.75} \mathrm{BW}$ daily (calculated iteratively assuming HP was equal to MEI), with $\mathrm{k}_{\mathrm{m}}$ estimated at 0.621 .

$$
\mathrm{HP}=310.0 \pm 36.7 \times \exp ^{\mathrm{MEI} \times 0.000954 \pm 0.000031}
$$

where $H P$ is daily heat production $\left(\mathrm{kJ} \mathrm{kg}^{-0.75} \mathrm{EBW}\right)$ and $M E I$ is daily $\mathrm{ME}$ intake $\left(\mathrm{kJ} \mathrm{kg}^{-0.75} \mathrm{EBW}\right)$.

The value of estimated $\mathrm{ME}_{\mathrm{m}}$ in the present study $\left(404.3 \mathrm{~kJ} \mathrm{~kg}^{-0.75} \mathrm{BW}\right)$ is $17 \%$ lower than that recommended by the NRC (2007), 21\% lower than values reported by the AFRC (1998), and $14 \%$ lower than values reported by the CSIRO (2007). These differences may be due to the different methodologies applied and/or genotype. For example, the recommendations of the NRC (2007) are based on dose-response trials, while the requirements estimated by the AFRC (1998) and CSIRO (2007) do not account for genotype differences. Rearing conditions and feed quality (i.e., digestibility) may also play an important role in dose-response trial outcomes (CSIRO, 2007). Furthermore, AFRC (1998) guidelines are based on respirometry trials, which have been reported to differ in terms of heat production (i.e., respirometry vs the comparative slaughter technique) and thus also in $\mathrm{ME}_{\mathrm{m}}$ (MCCRACKEN; RAO, 1989; WEBSTER, 1989).

Prieto et al. (1990) estimated similar $\mathrm{ME}_{\mathrm{m}}$ values for indigenous male goats $\left(443 \mathrm{~kJ} \mathrm{~kg}^{-0.75}\right.$ $\mathrm{BW}$ ), indicating that genotype may also affect $\mathrm{ME}_{\mathrm{m}}$. In cattle, studies have found lower $\mathrm{ME}_{\mathrm{m}}$ for more rustic compared to specialized beef cattle breeds (i.e., Bos indicus vs Bos taurus); this difference is allegedly due to differences in visceral organ mass and activity, protein turnover, internal fat and/or thermoregulation efficiency under tropical conditions (MARCONDES et al., 2013; OLIVEIRA, 2015). Although such phenomena have not yet been defined for goats, they may help to explain the findings of the present study. In goats, Bompadre et al. (2014) reported $\mathrm{ME}_{\mathrm{m}}$ values $69 \%$ lower (499.1 vs $294.3 \mathrm{~kJ} \mathrm{~kg}^{-0.75} \mathrm{EBW}$ ) and $\mathrm{k}_{\mathrm{m}}$ values $13 \%$ greater in Saanen goats than those obtained here. In addition, Souza et al. (2014) reported $\mathrm{ME}_{\mathrm{m}}$ values for indigenous goats $37.6 \%$ lower than those 
presented here. This variation may also be due to putative differences in maturity degree (ALMEIDA et al., 2016), supporting the genotype effect on maintenance requirements (NRC, 2007), even within indigenous goats.

Fasting heat production $\left(\mathrm{NE}_{\mathrm{m}}\right)$ is also generally assumed to be directly related to $\mathrm{ME}_{\mathrm{m}}$, as $\mathrm{ME}_{\mathrm{m}}=$ $\mathrm{NE}_{\mathrm{m}} / \mathrm{k}_{\mathrm{m}}$. Thus, sources of variation in $\mathrm{ME}_{\mathrm{m}}$ may be due to $\mathrm{NE}_{\mathrm{m}}$ and $\mathrm{k}_{\mathrm{m}}$ estimates. The estimated value of $\mathrm{k}_{\mathrm{m}}$ in the present study is within theoretical values for ruminants, from 0.60 up to 0.85 ; (ALMEIDA et al., 2015a; BOMPADRE et al., 2014; FERREIRA et al., 2015; FIGUEIREDO et al., 2016, 2017; LACHICA; AGUILERA, 2003; REID et al., 1980; SOUZA et al., 2014). This wide range of variation may be due to the fact that efficiencies of energy use $\left(\mathrm{k}_{\mathrm{m}}\right.$ and $\left.\mathrm{k}_{\mathrm{g}}\right)$ may change according to many factors related to environmental conditions, animal traits, and diet quality (AFRC, 1998; BIRKETT; DE LANGE, 2001; CORBETT; FREER, 2003). For example, volatile fat acids production has both distinct heat production (BALDWIN et al., 1980) and efficiencies of ME use (TEDESCHI et al., 2010). Thus, when comparing $\mathrm{ME}_{\mathrm{m}}$ across different scenarios, researchers should focus on explaining factors that may affect $\mathrm{k}_{\mathrm{m}}$ as well as fasting heat production.

The value of $\mathrm{k}_{\mathrm{g}}$ was estimated at 0.31 , assumed as the slope of Eq. [6], the regression equation of $\mathrm{MEI}_{\mathrm{g}}$ on RE (Eq. [6]; $P<0.01 ; \sigma_{\mathrm{e}}^{2}=1652.8$ ), further assuming zero RE when $\mathrm{MEI}_{\mathrm{g}}$ is equal to $\mathrm{ME}_{\mathrm{m}}$. As expected, the intercept estimate did not differ from zero $(P=0.67)$. The same value was reported by Figueiredo et al. (2017) and is within the wide range of values for $\mathrm{k}_{\mathrm{g}}$ reported in the literature; i.e., 0.30 to 0.65 (REID et al., 1980). Because protein deposition efficiency is lower than that reported for fat, varying from 0.1 to 0.40 for protein and from 0.60 to 0.84 for fat (ARC, 1980), goats depositing more protein than fat (e.g., intact males, growing animals) have lower $\mathrm{k}_{\mathrm{g}}$. For instance, $\mathrm{k}_{\mathrm{g}}$ in ruminants depends on both animal genotype and maturity degree.

$\mathrm{RE}=-6.14 \pm 10.1+0.3108 \pm 0.0121 \times \mathrm{MEI}_{\mathrm{g}}$

where $R E$ is daily retained energy $\left(\mathrm{kJ} \mathrm{kg}^{-0.75} \mathrm{EBW}\right)$, and $M E I_{g}$ is daily metabolizable energy intake above maintenance $\left(\mathrm{kJ} \mathrm{kg}^{-0.75} \mathrm{EBW}\right)$.

In the present study, total protein content in EBW increased at increasing rates for kids ranging from 5 to $25 \mathrm{~kg} \mathrm{BW}(\mathrm{P}<0.01$; Table 4$)$. As a result, the allometric equation fitted to describe EBW protein content had an allometric coefficient greater than one $(\mathrm{P}<0.01$; Table 4$)$. Similarly, fat content increased linearly for kids from 5 to $25 \mathrm{~kg}$ $\mathrm{BW}(\mathrm{P}<0.01$; Table 4). In this sense, the allometric coefficient estimated for fat was also heterogonic and positive ( $\mathrm{P}<0.01$; Table 4). Altogether, body energy content also increased at an increasing rate and had an allometric coefficient greater than one $(\mathrm{P}<0.01 ;$ Table 4). This may indicate that the studied animals were not mature at $25 \mathrm{~kg} \mathrm{BW}$, which is expected since it is likely that indigenous goats exhibit late-maturing growth. Using the first derivative of the allometric equations of total body protein and energy, with respect to EBW, the yielded estimates of $\mathrm{NP}_{\mathrm{g}}$ and $\mathrm{NE}_{\mathrm{g}}$ are presented in Eqs. [7] and [8] as follows:

$$
\begin{gathered}
\mathrm{NP}_{\mathrm{g}}=164.8 \times \mathrm{EBW}^{-0.098} \\
\mathrm{NE}_{\mathrm{g}}=3.24 \times \mathrm{EBW}^{0.41}
\end{gathered}
$$

where $N P_{g}$ and $N E_{g}$ are respectively the protein and energy concentration ( $\mathrm{g} \mathrm{kg}^{-1}$ and $\mathrm{MJ} \mathrm{kg} \mathrm{kg}^{-1}$ ) per unit of EBW gain, and $E B W$ is empty body weight $(\mathrm{kg})$. 
Table 4. Body composition and allometric equations of total body protein (g), fat (g), energy (MJ), or ash (g) content on the empty BW (EBW) to describe the net retention in intact in male indigenous kids.

\begin{tabular}{|c|c|c|c|c|c|c|c|c|c|c|c|}
\hline \multirow[b]{2}{*}{ Variable $^{1}$} & \multicolumn{4}{|c|}{ Parameter estimates $^{2}$} & \multirow[b]{2}{*}{$\begin{array}{c}\sigma_{\mathrm{e}}^{2} \\
(\times 1000)\end{array}$} & \multicolumn{3}{|c|}{$\mathrm{BW}, \mathrm{kg}^{3}$} & \multirow[b]{2}{*}{$\mathrm{SEM}^{4}$} & \multicolumn{2}{|c|}{$P$-value ${ }^{5}$} \\
\hline & $\beta_{0}$ & SE & $\beta_{1}$ & SE & & 5 & 15 & 25 & & Lin & Q \\
\hline Protein, g/kg EBW & 151.2 & 16.4 & 1.09 & 0.0433 & 30132 & 177.6 & 190.3 & 206.6 & 3.91 & $<0.01$ & $<0.01$ \\
\hline Fat, g/kg EBW & 6.65 & 4.97 & 1.85 & 0.209 & 485.4 & 94.8 & 117.5 & 154.0 & 9.87 & $<0.01$ & 0.95 \\
\hline Energy, MJ/kg EBW & 2.30 & 1.02 & 1.41 & 0.125 & 10.6 & 8.09 & 9.25 & 10.4 & 0.418 & 0.07 & $<0.01$ \\
\hline Ash, g/kg EBW & 85.3 & 37.6 & 0.935 & 0.126 & 604.9 & 66.9 & 71.8 & 66.7 & 3.62 & 0.33 & 0.62 \\
\hline
\end{tabular}

${ }^{1}$ Empty BW (EBW) may be estimated by the linear regression equation: $\mathrm{EBW}, \mathrm{kg}=0.508 \pm 0.117+0.770 \pm 0.0184 \times \mathrm{BW}, \mathrm{kg} ; \mathrm{n}$ $\left.=26 ; \sigma^{2}=1.53\right)$.

${ }^{2}$ Parameter estimates $\left(\beta_{0}\right.$ and $\left.\beta_{1}\right)$ of allometric equation, standard errors of parameter estimates (SE) and residual variance of the $\operatorname{model}\left(\sigma_{\mathrm{e}}^{2}\right)$.

${ }^{3}$ Observed body composition of male indigenous kids slaughtered at targeted BW of 5, 15 or $25 \mathrm{~kg}$.

${ }^{4} P$-value of Linear (Lin) and quadratic (Q) effects of slaughter weight.

${ }^{5}$ Standard error of the mean of observed body composition.

Daily $\mathrm{NP}_{\mathrm{g}}$ increased from $186.6 \pm 2.97$ to 214.3 $\pm 12.9 \mathrm{~g} \mathrm{CP} \mathrm{kg}^{-1} \mathrm{EBW}$ gain (Figure 1a), and $\mathrm{NE}_{\mathrm{g}}$ ranged from $5.39 \pm 1.49$ to $9.74 \pm 2.57 \mathrm{MJ} \mathrm{kg}^{-1}$ EBW gain (Figure 1b), as BW increased from 5 to $25 \mathrm{~kg}$ in male indigenous goats. Variation in mean $\mathrm{NP}_{\mathrm{g}}$ increased more than 4-fold, while $\mathrm{NE}_{\mathrm{g}}$ increased almost 2 times, as BW varied from 5 to $25 \mathrm{~kg}$. Although such variation is expected to increase with the mean, these results suggest that more uncertainty is associated with $\mathrm{NP}_{\mathrm{g}}$ than $\mathrm{NE}_{\mathrm{g}}$ estimates at greater weights. The estimates of the standard deviation in $\mathrm{NP}_{\mathrm{g}}, \mathrm{NE}_{\mathrm{g}}, \mathrm{NP}_{\mathrm{m}}$, and $\mathrm{ME}_{\mathrm{m}}$ values were obtained using Monte Carlo simulations, which may indicate the expected variation in energy and protein requirements for maintenance and weight gain within the studied population of indigenous goats.

Figure 1. Relationship between $\mathrm{NP}_{\mathrm{g}}$ (a) and $\mathrm{NE}_{\mathrm{g}}$ (b) and $\mathrm{BW}(\mathrm{kg})$ of male indigenous kids between 5 and $25 \mathrm{~kg} \mathrm{BW}$.

(a)

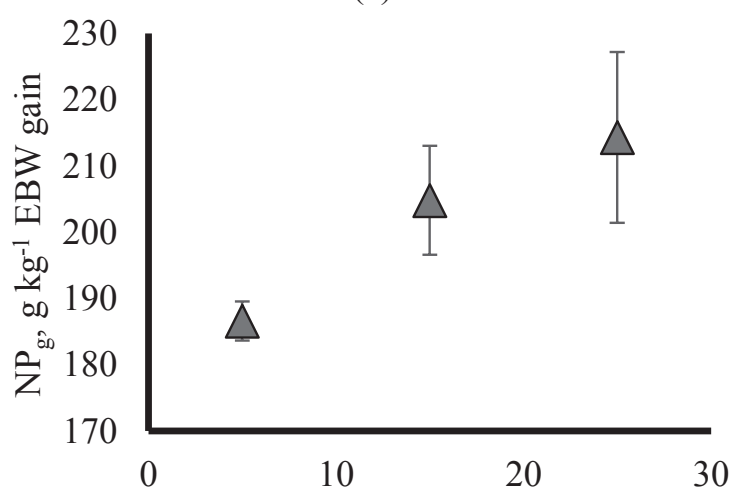

(b)

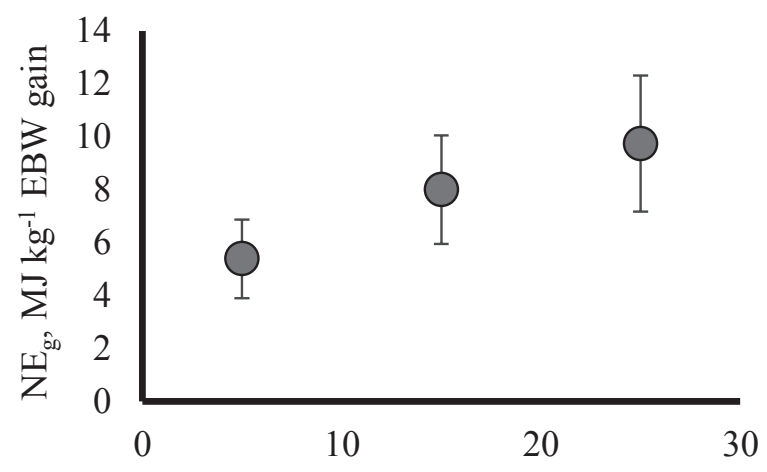

$\mathrm{BW}, \mathrm{kg}$ 


\section{Conclusions}

The results obtained in this study indicate that the net energy required for maintenance in indigenous kids is $310.1 \pm 36.7 \mathrm{~kJ} \mathrm{~kg}^{-0.75} \mathrm{EBW}$, with $\mathrm{ME}_{\mathrm{m}}$ estimated at $499.1 \pm 52.1 \mathrm{~kJ} \mathrm{~kg}^{-0.75}$ EBW and $\mathrm{k}_{\mathrm{m}}$ equal to 0.62 . It is recommended that indigenous kids weighing from 5 to $25 \mathrm{~kg}$ BW should ingest $4.45 \pm 1.24 \mathrm{~g} \mathrm{CP} \mathrm{kg}^{-0.75} \mathrm{EBW}$ to meet their protein requirements for maintenance. In addition, indigenous kids ranging from 5 to $25 \mathrm{~kg}$ BW require between $186.6 \pm 2.97$ to $214.3 \pm 12.9$ g CP, and $5.39 \pm 1.49$ to $9.74 \pm 2.57 \mathrm{MJ}$ to gain one kilogram EBW. Overall, the obtained values are valuable information that may help researchers and producers to adequately formulate diets for growing indigenous kids, preventing losses due to over- or underfeeding.

\section{References}

AGRICULTURALAND FOOD RESEARCH COUNCIL - AFRC. Agricultural and Food Research Council. The nutrition of goats. New York, NY: CAB International, $1998.118 \mathrm{p}$.

AGRICULTURALAND FOOD RESEARCH COUNCIL - AFRC. Energy and protein requirements of ruminants. Wallingford: CAB International, 1993. 159 p.

ALMEIDA, A. K.; RESENDE, K. T.; ST-PIERRE, N.; SILVA, S. P.; SOARES, D. C.; FERNANDES, M. H. M. R.; SOUZA, A. P., SILVA, N. C. D., LIMA, A. R. C.; TEIXEIRA, I. A. M. A. Energy requirements for growth in male and female Saanen goats. Journal of Animal Science, Champaign, v. 93, n. 8, p. 3932-3940, 2015 a.

ALMEIDA, A. K.; RESENDE, K. T.; SILVA, S. P.; SOARES, D. C.; FERNANDES, M. H. M. R.; TEIXEIRA, I. A. M. A. Protein requirements for growth in male and female Saanen goats. Revista Brasileira de Zootecnia, Viçosa, MG, v. 44, n. 11, p. 397-404, 2015 b.

ALMEIDA, A. K.; RESENDE, K. T.; TEDESCHI, L. O.; FERNANDES, M. H. M. R.; REGADAS FILHO, J. G. L.; TEIXEIRA, I. A. M. A. Using body composition to determine weight at maturity of male and female Saanen goats. Journal of Animal Science, Champaign, v. 94, n. 6, p. 2564-2571, 2016.
AGRICULTURAL RESEARCH COUNCIL - ARC. Nutrient requirements of ruminant livestock. Technical review by an Agricultural Research Council working party. Farnham Royal, Slough, Commonwealth Agricultural Bureau. 1980.

ASSOCIATION OF OFFICIAL AGRICULTURAL CHEMISTS - AOAC. Association of official Analytical Chemists. $13^{\text {th }}$ ed. Arlington, Washington: AOAC, 1980. $534 \mathrm{p}$.

BALDWIN, R. L.; SMITH, N. E.; TAYLOR, J.; SHARP, M. Manipulating metabolic parameters to improve growth rate and milk secretion. Journal of Animal Science, Champaign, v. 51, n. 6, p. 1416-1428, 1980.

BIRKETT, S.; DE LANGE, K. Limitations of conventional models and a conceptual framework for a nutrient flow representation of energy utilization by animals. British Journal of Nutrition, Wallingford, v. 86, n. 6, p. 647-659, 2001.

BLAXTER, K. L.; CLAPPERTON, J. L. Prediction of the amount of methane produced by ruminants. British Journal of Nutrition, Wallingford, v. 19, n. 4, p. 511-522, 1965.

BOMPADRE, T. F. V.; BOAVENTURA-NETO, O.; MENDONCA, A. N.; SOUZA, S. F.; OLIVEIRA, D.; FERNANDES, M. H. M. R., HARTER, C.; ALMEIDA, A. K.; TEIXEIRA, I. A. M. A. Energy requirements in early life are similar for male and female goat kids. Asian-Australasian Journal of Animal Sciences, Seoul, v. 27, n. 12, p. 1712-1720, 2014.

COMMONWEALTH SCIENTIFIC AND INDUSTRIAL RESEARCH ORGANISATION - CSIRO. Nutrient requirements of domesticated ruminants. Collingwood: CSIRO Publishing, 2007. 296 p.

CORBETT, J. L.; FREER, M. Past and present definitions of the energy and protein requirements of ruminants. Asian-Australasian Journal of Animal Sciences, Seoul, v. 16, n. 4, p. 609-624, 2003.

FAN, X.; SIVO, S.; KEENAN, S. SAS for Monte Carlo studies: a guide for quantitative researchers. Cary: Sas Institute Inc., 2002. 272 p.

FERNANDES, M. H. M. R.; RESENDE, K. T.; TEDESCHI, L. O.; FERNANDES, J. S.; SILVA, H. M.; CARSTENS, G. E.; BERCHIELLI, T. T.; TEIXEIRA, I. A. M. A.; AKINAGA, L. Energy and protein requirements for maintenance and growth of Boer crossbred kids. Journal of Animal Science, Champaign, v. 85, n. 4, p. 1014-1023, 2007. 
FERREIRA, A. C. D.; YÁÑEZ, E. A.; MEDEIROS, A. N.; RESENDE, K. T.; PEREIRA FILHO, J. M.; FERNANDES, M. H. M. R.; ALMEIDA, A. K.; TEIXEIRA, I. A. M. A. Protein and energy requirements of castrated male Saanen goats. Small Ruminant Research, Little Rock, v. 123, n. 1, p.88-94, 2015.

FIGUEIREDO, F. O. M.; BERCHIELLI, T. T.; RESENDE, K. T.; GOMES, H. F. B.; ALMEIDA, A. K.; SAKOMURA, N. K.; TEIXEIRA, I. A. M. A. Energy requirements for growth of pubertal female Saanen goats. Journal of Animal Physiology and Animal Nutrition, Chichester, v. 100, n. 2, p. 294-300, 2016.

FIGUEIREDO, F. O. M.; LEITE, R. F.; ST-PIERRE, N. R.; RESENDE, K. T.; ALMEIDA, A. K.; SOUZA, A. P.; TEIXEIRA, I. A. M. A. Energy and protein requirements of weaned male and female Saanen goats. Journal of Animal Physiology and Animal Nutrition, Chichester, v. 101, n. 5, p. 1014-1025, 2017.

FOOD AND AGRICULTURE ORGANIZATION OF THE UNITED NATIONS - FAO. Statistics division. FAOSTAT: Production/Live Animal. Rome: [S.1.], 2014. Available at: $<$ http://faostat3.fao.org $>$. Access at: 4 may 2016.

GALVANI, D. B.; PIRES, A. V.; SUSIN, I.; GOUVÊA, V. N.; BERNDT, A.; CHAGAS, L. J.; DÓREA, J. R. R.; ABDALLA, A. L.; TEDESCHI, L. O. Energy efficiency of growing ram lambs fed concentrate-based diets with different roughage sources. Journal of Animal Science, Champaign, v. 92, n. 1, p. 250-263, 2014.

LACHICA, M.; AGUILERA, J. F. Estimation of energy needs in the free-ranging goat with particular reference to the assessment of its energy expenditure by the 13C-bicarbonate method. Small Ruminant Research, Little Rock, v. 49, n. 3, p. 303-318, 2003.

LOFGREEN, G. P.; GARRET, W. N. A system for expressing net energy requirements and feed values for growing and finishing beef cattle. Journal of Animal Science, Champaign, v. 27, n. 3, p. 793-806, 1968.

MARCONDES, M. I.; TEDESCHI, L. O.; VALADARES FILHO, S. C.; GIONBELLI, M. P. Predicting efficiency of use of metabolizable energy to net energy for gain and maintenance of Nellore cattle. Journal of Animal Science, Champaign, v. 91, n. 10, p. 4887-4898, 2013.

MCCRACKEN, K. J.; RAO, S. D. Protein: energy interactions in boars of high lean deposition potential. In: HONING, Y van der; CLOSE, W. H. (Ed). Energy metabolism of farm animals. Wageningen: Pudoc., 1989. p. 13-16. (EAAP Publication n. 43).
NATIONAL RESEARCH COUNCIL - NRC. Nutrient requirements of small ruminants: sheep, goats, cervids and new world camelids. Washington: National Academic Press, 2007. 384 p.

OLIVEIRA, A. S. Meta-analysis of feeding trials to estimate energy requirements of dairy cows under tropical condition. Animal Feed Science and Technology, Amsterdam, v. 210, p. 94-103, 2015.

PRIETO, C.; AGUILERA, J.; LARA, L.; FONOLLÁ, J. Protein and energy requirements for maintenance of indigenous Granadina goats. The British Journal of Nutrition, Wallingford, v. 63, n. 2, p. 155-163, 1990.

REID, J. T.; WHITE, O. D.; ANRIQUE, R.; FORTIN, A. Nutritional energetics of livestock: some present boundaries of knowledge and future research needs. Journal of Animal Science, Champaign, v. 51, n. 1, p. 1393-1415, 1980.

SALAH， N.; SAUVANT, D.; ARCHIMÈDE， H. Nutritional requirements of sheep, goats and cattle in warm climates: a meta-analysis. Animal, Cambridge, v. 8, n. 9, p. 1439-1447, 2014.

SOUZA, A. P.; MEDEIROS, A. N.; CARVALHO, F. F. R.; COSTA, R. G.; RIBEIRO, L. P. S.; BEZERRA, A. B.; BRANCO, G. L. C.; SILVA, C. G. Energy requirements for maintenance and growth of Canindé goat kids. Small Ruminant Research, Little Rock, v. 121, n. 2, p. 255-261, 2014.

TEDESCHI, L. O.; FOX, D. G.; CARSTENS, G. E.; FERRELL, C. L. The partial efficiency of use of metabolisable energy for growth in ruminants. EAAP Publication no. 127, Parma, v. 127, n. 1, p. 519-529, 2010.

WEBSTER, A. J. Energy utilization during growth and reproduction (discussion). In. Energy Metabolism of Farm Animals, EAAP Publication no. 43, pp. 85-88 [Y van der Honing and WH Close, editors]. Wageningen: Pudoc., 1989.

WEST, J. W. Effects of heat-stress on production in dairy cattle. Journal of Dairy Science, Champaign, v. 86, n. 6, p. 2131-2144, 2003.

YAZDI, M. H.; MIRZAEI-ALAMOUTI, H. R.; AMANLOU, H.; MAHJOUBI, E.; NABIPOUR, A.; AGHAZIARATI, N.; BAUMGARD, L. H. Effects of heat stress on metabolism, digestibility, and rumen epithelial characteristics in growing Holstein calves. Journal of Animal Science, Champaign, v. 94, n. 1, p. 77-89, 2016. 
